\title{
Pengembangan model aquarobic exercise untuk pembakaran lemak pada overweight
}

\author{
Rahmat Sanusi *, W. Widiyanto \\ Program Studi Ilmu Keolahragaan, Program Pascasarjana, Universitas Negeri Yogyakarta. \\ Jalan Colombo No. 1, Karangmalang, Yogyakarta 55281, Indonesia. \\ * Corresponding Author. Email: kotaksuratedo@gmail.com \\ Received: 13 July 2018; Revised: 20 September 2018; Accepted: 21 September 2018
}

\begin{abstract}
Abstrak
Penelitian ini bertujuan menghasilkan model latihan alternatif yang layak untuk pembakaran lemak dan sebagai latihan non-traumatic untuk orang dengan overweight. Penelitian ini merupakan penelitian pengembangan (research and development) yang mengacu pada langkah yang dikembangkan Borg \& Gall melalui tahapan: pengembangan draf awal, model awal, model, uji coba produk, evaluasi dan revisi. Subjek uji coba terbatas sebanyak 3 orang dan subjek uji coba lapangan sebanyak 6 orang dengan kriteria mengalami masalah kelebihan berat badan (overweight). Pengumpulan data melalui uji pelaksanaan, penilaian ahli dengan lembar kuisioner, tes pengukuran denyut nadi dan pengukuran penurunan persentase lemak. Teknik analisis data menggunakan analisis deskriptif. Hasil penelitian menunjukkan bahwa model aquarobic exercise untuk pembakaran lemak ditinjau dari bentuk, isi dan tujuan latihan oleh ahli kebugaran jasmani, ahli fisiologi dan ahli renang dikategorikan "Baik". Hasil data pre dan post test menujukkan peningkatan nilai rata-rata denyut nadi dan penurunan persentase lemak. Disimpulkan bahwa model aquarobic exercise layak dan efektif untuk pembakaran lemak pada overweight.
\end{abstract}

Kata Kunci: aquarobic exercise, lemak, denyut nadi, overweight

\section{Developing aquarobic exercise for burning fat in overweight people}

\begin{abstract}
The study aims at generating a feasible exercise model for burning fat and for serving as nontraumatic exercise for overweight people. The study is a research and development that refers to the stages that have been developed by Borg \& Gall. These stages are as follows: (1) preliminary draft development; (2) preliminary model; (3) product testing; (4) evaluation; and (5) revision. Then, the subjects in the small-scale testing were 3 people while the subjects in the field testing were 6 people who had overweight problems. The data were gathered through implementation test, expert judgment by means of questionnaire, pulse measurement test and fat percentage decrease measurement. In analysing the data, the analytical descriptive technique was implemented. The results of the study show that according to the physical fitness experts, physiological experts and swimming experts the aquarobic exercise for burning fat belongs to the "Good" category in terms of exercise form, content and objective. Then, the data that have been gathered from pre-test and the post-test show improvement on the mean score of pulse rate and fat percentage decrease. Last but not the least, it might be concluded that the aquarobic exercise model is feasible and effective for burning the fat among the overweight people.
\end{abstract}

Keywords: aquarobic exercise, fat, heart rate, overweight

How to Cite: Sanusi, R., \& Widiyanto, W. (2018). Pengembangan model aquarobic exercise untuk pembakaran lemak pada overweight. Jurnal Keolahragaan, 6(2), 139-149. doi:https://doi.org/10.21831/jk.v0i0.8560

https://doi.org/10.21831/jk.v0i0.8560

\section{PENDAHULUAN}

Kelebihan berat badan diartikan sebagai kehilangan kendali dalam menjaga berat tubuh ideal. Secara sederhana, berat badan ideal dapat dihitung dengan (Tinggi Badan - 100) 90\% (Hutabarat, 2016). Jika melebihi 10\% dari berat badan ideal dikategorikan sebagai overweight 
dan jika melebih $20 \%$ dari berat badan ideal diketegorikan sebagai obesitas. Pengukuran berat badan ideal dapat juga dihitung dengan menggunkan rumus Body Mass Index (BMI) dengan rumus berat badan $(\mathrm{kg})$ dibagi dengan tinggi badan pangkat dua $\left(\mathrm{m}^{2}\right)$ dan juga dapat menggunakan rumus dengan mengukur lingkar perut.

Banyak faktor penyebab terjadinya penumpukan lemak yang berlebih hingga menjadi overweight hingga obesitas. Gen/faktor keturunan menjadi pemicu utama meningkatnya berat badan secara drastis. Secara genetik orang dengan overweight memiliki sel lemak yang lebih banyak (hyperplasia) dan ukuran sel lemak yang besar (hyperthropy). Sistem metabolisme juga menjadi salah satu faktor genetik pada orang yang mengalami masalah kenaikan berat badan. Faktor lainnya yang menjadi penyebab meningkatnya kadar lemak pada tubuh adalah pilihan makanan dan pola hidup tidak sehat. Makanan cepat saji sebagai pilihan utama. Kondisi ini diperburuk dengan sedikitnya waktu dalam melakukan aktivitas fisik dan berolahraga mengakibatkan tidak terjadinya keseimbangan energi, yakni energi yang masuk lebih besar lebih besar dari pada energi yang dikeluarkan. Dengan demikian energi yang tersimpan dan menumpuk menjadi lemak yang berefek pada meningkatnya berat badan.

Berdasarkan hasil Riset Kesehatan Dasar yang dilakukan pada tahun 2010 memaparkan hasil riset kesehatan nasional yang menyimpulkan status gizi pada kelompok usia dewasa (18 tahun ke atas) didominasi oleh masalah obesitas. Angka obesitas pada perempuan cendrung lebih tinggi. Penduduk yang mengalami obesitas lebih tinggi pada penduduk perkotaan, berpendidikan tinggi dan berpendapatan tinggi. Secara nasional untuk usia diatas 18 tahun dengan masalah overweight sejumlah $10 \%$ dan obesitas sejumlah $11,7 \%$ prevalensi laki-laki yang mengalami obesitas lebih rendah yaitu $16,3 \%$ dibandingkan perempuan $29,6 \%$. Secara umum angka kelebihan berat badan untuk usia dewasa tergolong cukup tinggi. Pada tahun 2013 Riset Kesehatan Dasar kembali memaparkan hasil riset kesehatan nasional. Salah satu permasalahan yang sangat mengkhawatirkan adalah secara nasional masalah kegemukan masih terbilang cukup tinggi. Dengan jumlah populasi penduduk 249,9 juta jiwa, angka masyarakat Indonesia yang mengalami masalah kelebihan berat badan terbilang masih cukup tinggi. Usia dewasa 18 tahun ke atas mencapai 13,5\%. Untuk usia dewasa di atas 18 tahun terjadi peningkatan masalah kontrol berat yang cukup signifikan.
Untuk laki-laki dewasa yang mengalami masalah kelebihan berat badan sebanyak $13,3 \%$ dan untuk wanita sebanyak $21,4 \%$. Untuk laki-laki dewasa yang mengalami obesitas pada tahun 2013 sejumlah 19,7\% lebih tinggi dari tahun 2010 sejumlah $7,8 \%$. Kenaikan berat badan perempuan dewasa $32,9 \%$ naik 17,5\% dari tahun 2010 (15,5\%) (Kementerian Kesehatan Republik Indonesia, 2013, p.285).

Olahraga merupakan solusi untuk meningkatkan kesehatan, seperti menjaga berat badan. Salah satunya adalah dengan olahraga aerobik. Kebutuhan oksigen yang banyak pada latihan aerobik mendukung dalam proses pembakaran lemak. Latihan ini membutuhkan waktu lebih lama yaitu minimal 20 menit. Jika kurang dari itu maka aktivitas olahraga tidak membakar lemak melainkan hanya membakar karbohidrat sebagai sumber energi dan pengeluaran cairan (keringat).

Keterbatasan orang overweight dalam melakukan gerakan latihan seperti melompatmelompat menjadi hal penting saat melakukan latihan. Orang yang memiliki masalah obesitas cenderung tidak dapat berdiri lebih lama untuk melakukan latihan yang bergerak dan aktif, terutama gerakan-gerakan full move ke kiri ke kanan, ke belakang dan ke depan dikerenakan kemampuan menopang berat badan tidak maksimal. Disimpulkan belum berkembangnya secara optimal latihan yang layak, menyenangkan dan aman, terutama mengatasi/ meminimalisir risiko osteoarthritis untuk membantu orang dengan masalah berat badan (overweight).

Pada dasarnya semua latihan memiliki tujuan untuk menyehatkan tubuh. Tidak seperti di darat, latihan di air diketahui sangat unik dan santai. Gerakan-gerakan di dalam air dapat meningkatkan pengeluaran energi. Setiap gerakan yang dilakukan di air memiliki nilai kepadatan lebih besar 700x dibandingkan di luar. (Bocalini, Serra, Murad, \& Levy, 2008, p.265). Berlari di luar air akan sangat mudah namun akan membutuhkan tenaga yang ekstra agar dapat berlari di dalam air, menendang akan sangat ringan jika di luar air dan akan menjadi sangat berat jika di dalam air. Kemampuan mengapung air dapat meredam efek dari berat badan yang dapat mempermudah pergerakan dan menurunkan tekanan pada tulang yang dapat meminimalisirkan terjadinya cedera saat latihan.

Belum banyak berkembang latihan-latihan di air, terutama yang memiliki tujuan untuk meningkatkan kebugaran jasmani. Oleh karena itu sangat diperlukan sebuah model latihan di air untuk mengatasi permasalahan yang sering di- 
alami orang dengan overweight, selain itu untuk menciptakan jenis latihan yang lebih bervariasi.

\section{Aquarobic Exercise}

Ada tiga aspek utama pada aktivitas fisik yang dilakukan di air. Tomihiro \& Shimizu (2004, p. 9) membagi aktivitas di air menjadi tiga kelompok yaitu aquatic sport, aquatic exercise dan aquatic therapy. Aqutic sport adalah berkaitan dengan olahraga-olahraga yang dilakukan di air, seperti renang, polo dan lain sebagainya. Aquatic theraphy yang berperan sebagai media penyembuhan atau rehabilitasi, seperti rehabilitasi pasca cedera angkle, lutut dan lain sebagainya. Aquatic exercise merupakan latihan-latihan fisik yang dilakukan di air dengan tujuan untuk mendapatkan kebugaran. Menurut Verhargen, Cardoso, \& Bierma-Zeinstra (2012, p.336) aquatic exercise sering digunakan untuk menjaga atau memperbaiki fungsi otot dan persendian terutama adalah osteoathritis. Menggunakan air sebagai media latihan dapat menurunkan risiko cedera pada otot dan persendian. Gappmaier, Lake, Nelson, \& Fisher (2006, p.567) menyatakan bahwa latihan aquarobic memberikan hasil perubahan tubuh yang sama seperti latihan di darat jika intensitas, durasi dan frekuansi yang sama. Dilihat dari peningkatan denyut jantung setelah melakukan latihan selama 11 minggu, tidak terdapat perbedaan yang signifikan antara latihan aerobik di air dengan latihan aerobik di darat. Latihan di air memberikan keuntungan dari sisi daya apung, suhu dan variasi dalam latihan.

\section{Konsep Pengembangan Aquarobic Exercise Untuk Pembakaran Lemak}

Konsep pengembangan model latihan ini meliputi mengembangkan suatu model latihan yaitu aquarobic exercise untuk program pembakaran lemak yang bersifat aman dan menyenangkan. Memaksimalkan pengeluaran energi/ kalori (in-out energi). Sifat kekentalan air dapat menghambat pergerakan-pergerakan selama berada di air yang dapat menghasilkan beban latihan yang besar berasal dari tubuh sendiri bukan menggunakan beban dari luar. Menciptakan suatu model latihan sebagai latihan alternatif (non traumatic) untuk program penurunan berat badan.

\section{Pengertian Latihan}

Latihan secara umum didefinisikan sebagai aktivitas yang dilakukan secara sistematis dan terprogram dalam jangka waktu yang lama yang tujuannya meningkatkan dan mengembangkan kemampuan. Secara garis besar pengertian latihan difokuskan kepada realisasi atau pelaksanaan dari materi-materi atau betuk-bentuk latihan yang telah dipersiapkan dan direncanakan sebelumnya (proses sistematis) dengan prinsip penambahan intensitas/dosis/beban secara bertahap yang fokus utamanya ialah meningkatkan kemampuan fisik guna meningkatkan kemampuan prestasi olahraga. Suharjana, (2013, p.45). Latihan erat kaitannya dengan olahraga. Menurut Penggalih, Hardiyanti, \& Sani (2015, p.219) Olahraga adalah suatu bentuk latihan fisik yang dapat meningkatkan kebugaran jasmani apabila dilakukan dengan frekuensi dan intensitas yang tepat dan sesuai. Olahraga yang benar akan memberikan hasil peningkatan kerja sistem respirasi, sistem kardiovaskular, menguatkan otot-otot rangka dan daya tahan tubuh.

\section{Frekuensi Latihan}

Frekuensi latihan dapat diartikan sebagai seberapa sering latihan tersebut dilakukan. Menurut Suharjana (2013, p.47) menyatakan bahwa frekuensi merujuk pada jumlah latihan yang dilakukan selama satu minggu. Sukadiyanto (2011, p.32) menjelaskan bahwa frekuensi adalah jumlah latihan yang dilakukan dalam periode waktu tertentu (dalam satu minggu), periode waktu yang digunakan untuk menghitung jumlah frekuensi adalah satu mingguan. Untuk jenis latihan aquarobic exercise ini, agar mendapatkan hasil maksimal disarankan dilakukan dengan frekuensi $3 x$ per minggu dan minimal $2 x$ per minggu

\section{Intensitas Latihan}

Intensitas dapat dikatakan sebagai dosis atau takaran latihan yang dijalankan. Intensitas latihan adalah berat atau ringannya beban atau tekanan fisik dan psikis yang harus diselesaikan selama latihan (Chan, 2012; Suharjana (2013, p. 45). Penggalih, Hardiyanti, \& Sani (2015, p.219) menjelaskan bahwa intensitas latihan adalah berat ringannya beban latihan yang menjadi pertimbangan berikutnya, setelah memperhatikan tipe latihan yang tepat. Intensitas latihan merupakan salah satu pedoman dalam penerapan prinsip beban berlebih. Parameter intensitas latihan yang sering digunakan salah satunya adalah denyut jantung.

\section{Time (Waktu atau Durasi Latihan)}

Suharjana (2013, p. 47) menjelaskan bahwa durasi dapat berarti waktu, jarak atau kalori. Durasi merujuk pada lama waktu yang 
dibutuhkan. Sukadiyanto (2011, p.31) menjelaskan bahwa durasi adalah ukuran yang menujukkan lamanya pemberian rangsangan (lamanya latihan). Untuk durasi latihan produk ini peneliti menyarankan latihan dilakukan selama 25 hingga 35 menit dengan gerakan latihan kontinyu.

\section{Tipe Latihan}

Suharjana (2013, p.47) menyatakan bahwa tipe latihan adalah bentuk atau model yang digunakan untuk latihan. Untuk tipe model latihan ini ialah tipe dengan intensitas variatif, karena latihan ini terdiri dari beberapa gerakan-gerakan seperti senam aerobik pada umumnya dengan irama gerakan sedang, ritmik dan kontinyu

\section{Pengertian Latihan Aerobik}

Aerobik adalah latihan yang banyak membutuhkan oksigen sebagai sumber energi dengan tidak menyisakan asal laktat yang dapat menyebabkan kelelahan. Biasanya latihan aerobik dilakukan dalam waktu yang lama. Jika latihan dilakukan lebih dari 3 menit maka latihan dapat dikategorikan sebagai aerobik. Sementara latihan anaerobik adalah latihan yang membutuhkan sedikit oksigen dan kadang tidak sama sekali menggunakan oksigen selama latihan dengan menyisakan asam laktat yang menyebabkan kelelahan.

\section{Aerobik untuk Membakar Lemak}

Latihan aerobik melibatkan banyak oksigen dalam aktivitasnya. Hal ini sejalan dengan proses pembakaran lemak yang membutuhkan oksigen untuk diubah menjadi energi. Lemak merupakan sumber energi cadangan kedua setelah karbohidrat. Jika tidak digunakan, lemak akan terus menumpuk dan semakin banyak. Hagag (2013, p.105) menjelaskan bahwa latihan aerobik dari moderat hingga tinggi memberikan hasil untuk memperbaiki lipid dalam darah. Latihan aerobik memberikan efek pada peningkatan metabolisme.

Sharkey (1990, p.25) menjelaskan bahwa latihan aerobik akan menyebabkan epinephrine menstimulasi membrane sel lemak dan aktif memicu untuk melepaskan asam lemak bebas ke dalam aliran darah. Asam lemak bebas kemudian berjalan menuju otot untuk bekerja sebagai sumber energi. Selama latihan berat, akan diproduksi asam laktat pada otot dan diblok oleh epinephrin. Dengan demikian, mengurangi asam laktat, akan menjadikan asam lemak bebas sebagai energi. Untuk latihan yang ditujukan untuk pembakaran lemak, menggunakan jenis aerobik dengan durasi 20-28 menit dengan intensitas sedang. (Suharjana, 2013, p.47). Jika kurang dari itu maka lemak tidak terbakar.

\section{Pengertian Lemak}

Lemak merupakan suatu kelompok organik yang tidak larut dalam air (Mahato, 2005). Dalam bentuk lain disebut juga sebagai lipid yang terdiri dari asam lemak (free faty acid), plasma triacyligycerol/trygecerids, asam lemak esensial, kolesterol, lipoproteins (LDL dan HDL) dan lain sebagai-nya. Kang (2012, p.56) lipid merupakan kompo-nen penting yang selalu dilibatkan dalam sistem fisiologi. Untuk sebagian orang, kebutuhan lipid menjadi berlebih dapat memberi pengaruh tidak sehat pada tubuh. Lipid sering juga disebut dengan lemak atau minyak. Kelas utama lipid terbagi menjadi beberapa jenis seperti asam lemak, triglycerid, phospolipids dan sterol.

\section{Fungsi Lemak}

Lemak berperan penting dalam proses metabolisme tubuh sebagai salah satu sumber energi. Lemak sebagai sumber energi dua kali lebih besar dari protein dan karbohidrat (Akoso, 2012). Lemak lebih banyak disimpan pada umumnya di bawah kulit (jaringan adipose), jaringan otot dan pada bagian tubuh tertentu seperti perut, lengan, paha dan pinggul. Lemak disimpan dalam bentuk triglycerid dalam jumlah yang banyak tampak jelas pada bagian perut, sedangkan dalam bentuk kecil terdapat pada sirkulasi yang terintegrasi dengan lipoprotein yang dikenal dengan istilah LDL atau Low Density Lipoprotein/ bad cholesterol dan HDL atau High Density Lipoprotein/ good cholesterol.

\section{Proses Pembakaran Lemak}

Setiap aktivitas fisik yang dilakukan manusia entah secara sadar atau tidak, akan menyebabkan tranformasi energi yang disebut metabolisme. Dalam keadaan istirahat, tidur maupun melakukan latihan berat tubuh melakukan proses metabolisme untuk mengubah sumber energi menjadi energi yaitu pembakaran karbohidrat dan lemak dengan melibatkan panas tubuh yang diukur dengan calorimetry atau kalori. Plowman \& Smith (2014, p. 93) mengemukakan kata kalorimetri diambil dari kata kalori yang merupakan unit dasar dari energi panas. Calorimetry adalah ukuran untuk energi panas yang dilepaskan atau terbentuk dari proses metabolisme. McArdle, Frank, \& Katch (2010, p.112) memperjelas bahwa satu kilogram kalori atau $\mathrm{kCal}$ definisi untuk nilai makanan yang 
mengandung kalori dan digunakan sebagian besar berhubungan pada makanan dan transfer energi manusia. Dengan persamaan $1 \mathrm{kCal}=$ 1000 kalori $=4,418 \mathrm{~J}$.

\section{Pengertian Overweight}

Kelebihan berat badan adalah kehilangan kendali seseorang dalam mengontrol berat badan normal dibagi menjadi dua kelompok utama yaitu overweight dan obesitas. Overweight dan obesitas adalah kondisi seseorang kehilangan pengaturan berat badan. Ukuran berat badan normal atau Body Mass Indeks (BMI) dapat dilakukan dengan menghitung secara manual dengan rumus berat badan dalam kilogram $(\mathrm{kg})$ dibagi dengan tinggi badan dalam meter pangkat dua $\left(\mathrm{m}^{2}\right)$.

Berdasarkan pemaparan tersebut, maka penelitian ini dilakukan untuk menghasilkan model latihan alternatif yang layak untuk pembakaran lemak dan sebagai latihan non-traumatic untuk orang dengan overweight.

\section{METODE}

Jenis penelitian ini adalah penelitian pengembangan (Research and Development) Borg and Gall (Sugiyono, 2013, p.298) menyebutkan bahwa penelitian pengembangan merupakan proses atau metode yang digunakan untuk memvalidasi dan mengembangkan produk. Pengembangan produk ini tidak hanya dalam bentuk benda, seperti buku teks, software, alatalat, tetapi juga dalam bentuk metode mengajar, program latihan dan lain sebagainya.

Penelitian skala kecil dilakukan pada bulan Oktober 2015 di kolam renang Universitas Negeri Yogyakarta dan Uji coba skala besar dilakukan pada bulan Desember 2015 di kolam renang Uniiversitas Negeri Yogyakarta.

\section{Prosedur Penelitian Pengembangan}

Menurut Borg \& Gall (Sugiyono, 2013, p.298) ada 10 tahapan pengembangan yang dipersingkat sesuai kebutuhan menjadi tujuh langkah penelitian pengembangan, yaitu sebagai berikut:

Potensi Masalah, Mengumpulkan Informasi dan Observasi Lapangan.

Peneliti mengamati latihan program penurunan berat badan yang umumnya sering dilakukan adalah jogging, terutama pada wanita. Hampir setiap sore, di sekitar wilayah kampus UNY terutama di depan rektorat banyak ditemui orang dengan masalah berat melakukan joging. Tinjauan di lapangan dan akademik menunjuk- kan bahwa secara nasional dari tahun 2007-2013 angka masyarakat Indonesia yang mengalami masalah kenaikan berat badan meningkat signifikan. Beberapa kajian teori juga menunjukan belum berkembangnya secara optomal adanya latihan aquatic yang ditujukan untuk program pembakaran lemak. Dengan demikian peneliti menyimpulkan bahwa perlu adanya suatu model latihan yang bersifat menyenangkan dan efektif untuk program pembakaran lemak.

\section{Analisis Informasi}

Analisis pertama dilakukan dengan dengan studi pustaka. Studi pustaka betujuan menguatkan landasan berpikir. Permasalahan apa yang sering dialami oleh orang dengan overweight dalam melakukan program latihan pembakaran lemak untuk proses penurunan berat badan. Penulis mencoba menggali lebih banyak informasi kepada orang yang mengalami masalah berat badan (overweight) mengenai kendala-kendala dalam usaha latihan membakar lemak. Selain itu, pengumpulan informasi juga diperoleh melalui rekan-rekan instruktur senam yang sering mendapatkan keluhan dari klien. Masalah yang sering dihadapi para instruktur adalah tidak konsistennya pasien dengan masalah berat badan untuk menyelesaikan program latihan disebabkan rasa bosan.

\section{Desain Produk Awal}

Setelah proses analisis, peneliti mulai merancang kerangka untuk membuat suatu produk yang membantu mengatasi permasalahan orang yang mengalami masalah kenaikan berat badan (overweight). Nantinya diharapkan produk ini dapat bermanfaat dalam membakar lemak untuk proses penurunan berat badan. Ada beberapa langkah peneliti dalam mengembangkan produk awal. Pertama, jenis dan karakteristik latihan apa yang tepat untuk orang dengan overweight dalam proses pembakaran lemak. Kedua, gerakangerakan apa yang akan dikembangkan untuk mendukung latihan yang akan dikembangkan. Yang terakhir berdasarkan langkah-langkah tersebut akhirnya peneliti mengembangkan sebuah produk yaitu latihan di air untuk program pembakaran lemak bagi orang dengan overweight.

Validasi Desain dan Perbaikan Desain (Revisi Produk)

Sebelum melakukan uji coba sekala kecil, maka dilakukan validasi terlebih dahulu terhadap rancangan model aquatic aerobic exercise untuk program penurunan berat badan. Validasi ini 


\section{Jurnal Keolahragaan 6 (2), 2018 - 144}

Rahmat Sanusi, W. Widiyanto

bertujuan untuk mendapatkan pengesahan dan reliabilitas pada model aquatic aerobic exercise dan mendapatkan masukan dari para pakar terhadap produk awal yang dikembangkan. Validasi ini dilakukan oleh pakar yang terdiri dari tiga ahli, yaitu pertama, Prof. Dr. Suharjana, M.Kes yang merupakan pakar kebugaran jasmani. Kedua Dr. dr. Rachmah Laksmi Ambardini, M.Kes yang merupakan pakar fisiologi olahraga dan Nur Indah Pangestu, M.Or. yang merupakan pakar olahraga renang

\section{Uji Coba Produk Skala Kecil dan Revisi}

Uji coba lapangan dengan skala kecil dilakukan di kolam renang UNY dengan subjek perempuan berjumlah tiga orang dengan kriteria overweight. Pada uji coba skala kecil ini peneliti ada 2 komponen penting yang menjadi penilaian peneliti. Pertama, berkaitan dengan gerakangerakan latihan.

Kedua, berkaitan dengan kelayakan latihan aquatic aerobic exercise. Latihan ini ditujukan untuk pembakaran lemak dengan memperkirakan penurunan persentase lemak, dengan mengukur denyut nadi dan mengukur persentase lemak setelah melakukan latihan dengan omron body fat monitor.

\section{Uji Coba Skala Besar dan Revisi}

Setelah direvisi pada uji coba skala kecil, produk siap diujicobakan pada skala besar dengan jumlah subjek enam orang yang mengalami masalah berat badan.

\section{Pembuatan Produk Final}

Setelah melalui tahapan revisi, maka dilakukan penyusunan dan pembuatan produk yang terdiri dari video tutorial dan buku panduan yang diberi judul model latihan aquarobic exercise untuk pembakaran lemak overweight.

\section{Jenis Data}

Jenis data yang diperoleh dalam penelitian pengembangan ini ialah data kualitatif dan kuantitatif. Data kualitatif diperoleh dari hasil wawancara dengan sampel uji coba, dengan rekan praktisi olahraga, dan masukan dari validator. Untuk data kuantitatif diperoleh dari hasil peningkatan denyut nadi, persentase penurunan lemak dan lembar kuesioner validator.

\section{Intrumen Pengumpulan Data}

\section{Lembar Kuesioner}

Lembar kuesioner berisi pertanyaan-pertanyaan terkait dengan model yang dikembangkan. Lembar kuesioner ditujukan kepada subjek uji coba untuk menilai pelaksanaan model. Kedua, lembar kuesioner ditujukan kepada validator untuk menilai kelayakan model berkaitan dengan materi dari model yang dikembangkan. Lembar kuesioner teridiri dari beberapa pertanyaan dengan lima opsi pilihan nilai untuk setiap pertanyaan yaitu nilai 1 (Sangat Kurang), 2 (Kurang), 3 (Cukup), 4 (Baik), dan 5 (Sangat Baik)

Pengukuran Denyut Nadi, Penurunan Persentase Lemak dan Skinfold Cliper

Pengukuran denyut nadi dan penurunan persentase lemak untuk menilai kelayakan dan efektivitas produk ditinjau proses pembakaran lemak selama latihan.

Pengukuran denyut nadi selama satu menit yang dilakukan dengan cara palpalasi arteri sebelum dan sesudah melakukan latihan. Selanjutnya memperkirakan persentase lemak, dengan menggunakan alat omron fat mody monitor dan perhitungan manual dengan alat skinfold caliper. Perhitungan skinfold, melibatkan pengukuran titik-titik tertentu yang disepakati oleh para ahli untuk wanita yaitu bicep, triceps, front thigh, dan illiaca crest. Penghitungan manual persentase lemak dengan menggunakan rumus Siri 1959.

\section{Teknik Analisis Data}

Teknik analisis yang digunakan dalam penelitian ini adalah analisis deskriptif. Data dalam penelitian terdiri dari data kualitatif dan data kuantitatif. Untuk data kuantitatif adalah dengan menggambarkan rata-rata mean different pre test dan post test. Teknik mean different pre test dan post test digunakan untuk melihat selisih sebelum dan sesudah melakukan latihan.

Data berikutnya adalah data kualitatif berupa penilaian, masukan dan kritik dari para ahli. Saran, masukan dan kritik menjadi bahan dalam perbaikan model. Data kualitatif akan dikonvensi ke data kuantitatif, yang berupa pertanyaan dengan lima bentuk skor, yaitu skor kategori sangat baik (nilai 5), baik (nilai 4), cukup (nilai 3), kurang (nilai 2) dan sangat kurang (nilai 1). Konvensi dari data kuantitatif ke kualitatif yang diadaptasi dari Sukardjo (Fanny, \& Suardiman, 2013; Qodriyah, \& Wangid, 2015; Sukardjo, 2015). 
Tabel 1. Konversi Data Kuantitatif Ke Data Kualitatif Dengan Skala 5

\begin{tabular}{|c|c|c|}
\hline $\begin{array}{c}\text { Data } \\
\text { kuantitatif }\end{array}$ & Rentang & $\begin{array}{c}\text { Data } \\
\text { kualitatif }\end{array}$ \\
\hline 5 & $\mathrm{X}>\mathrm{Xi}+1,80$ Sbi & Sangat Baik \\
\hline 4 & $\begin{array}{c}\mathrm{Xi}+0,06 \mathrm{Sbi}<\mathrm{X}<\mathrm{Xi} \\
+1,80 \mathrm{Sbi}\end{array}$ & Baik \\
\hline 3 & $\begin{array}{c}\mathrm{Xi}-0,60 \mathrm{Sbi}<\mathrm{X} \leq \mathrm{Xi} \\
+0,60 \mathrm{Sbi}\end{array}$ & Cukup \\
\hline 2 & $\begin{array}{c}\mathrm{Xi}-1,80 \mathrm{Sbi}<\mathrm{X} \leq \mathrm{Xi} \\
-0,60 \mathrm{Sbi}\end{array}$ & Kurang \\
\hline 1 & $\mathrm{X} \leq \mathrm{Xi}-1,80 \mathrm{Sbi}$ & $\begin{array}{l}\text { Sangat } \\
\text { Kurang }\end{array}$ \\
\hline
\end{tabular}

\section{HASIL DAN PEMBAHASAN}

\section{Analisis Data Hasil Uji Coba Skala Kecil}

Untuk penilaian uji pelaksanaan produk, sampel memberikan penilaian pada kuesioner terhadap latihan yang telah dilaksanakan. Respons dari sampel yang menjadi tester dalam produk ini merupakan penilaian yang sangat penting bagi peneliti terhadap keterimaan produk nanti untuk digunakan orang banyak. Kuesioner beirisi pertanyaan terkait dengan proses latihan dan produk yang dikembangkan. Penilaian dari sampel menjadi bahan evaluasi bagi sampel dalam memperbaiki produk nantinya. Dari uji pelaksanaan, diperoleh hasil dari kuesioner yang telah diberikan kepada sampel seperti Tabel 2.

Tabel 2. Distribusi Frekuensi Hasil Uji Pelaksanaan kualitas Model Pada Uji Coba Skala kecil

\begin{tabular}{|c|c|c|c|c|}
\hline No. & Interval & Kategori & $\mathrm{f}$ & $\%$ \\
\hline 1. & $>4.21$ & Sangat Baik & & \\
\hline 2. & $3.41-4.21$ & Baik & 3 & 100 \\
\hline 3. & $2.61-3.40$ & Cukup & & \\
\hline 4. & $1.80-2.60$ & Kurang & & \\
\hline 5. & $<1.79$ & Sangat Kurang & & \\
\hline \multicolumn{3}{|c|}{ Total } & 3 & 100 \\
\hline
\end{tabular}

Berdasarkan penilaian aspek kualitas produk yang dikembangkan dari sisi keamanan, kenyamanan dan kseluruhan rangkaian latihan direspons secara baik dengan penilaian skor ratarata 3,8 termasuk dalam kategori "Baik".

Dari data tersebut dijelaskan untuk nilai di atas 4.21 dengan kategori "Sangat Baik" tidak ada, untuk nilai 3,41-4,21 dengan kategori "Baik" mendapat frekuensi 3 orang. Untuk rentang nilai dari 2.61 sampai 3.40 dengan kategori "Cukup" tidak ada, untuk nilai dari 1.80-2.60 dengan kategori "Kurang" tidak ada dan untuk nilai di bawah 1.76 dengan kategori "Sangat Kurang" tidak ada.
Pengukuran berikutnya ialah nilai pre dan post test. Penelitian hanya pada pengujian respon. Penilaian pre dan posttest berkaitan dengan respons fisiologis tubuh terhadap latihan yang telah dilaksanakan. Data pre dan posttes diperoleh dengan mengukur peningkatan denyut nadi per menit dan memperkirakan penurunan persentase lemak setelah melakukan latihan. Hasil data tersebut kemudian dianalisis untuk melihat rata-rata pre dan posttest agar dapat melihat apakah terdapat selisih perbedaan ratarata (mean different) ketika sebelum dan sesudah melakukan latihan. Penilaian pre dan posttest diperoleh data seperti pada Tabel 3.

Tabel 3. Data Pre dan Post Skala Kecil

\begin{tabular}{cccrc}
\hline \multirow{2}{*}{ Nama } & \multicolumn{2}{c}{ DN/ menit } & \multicolumn{2}{c}{ Lemak } \\
\cline { 2 - 5 } & Pre & Post & Pre & Post \\
\hline Riski & 84 & 126 & $31.1 \%$ & $31.0 \%$ \\
Lia & 84 & 126 & $30.6 \%$ & $30.5 \%$ \\
Vina & 90 & 120 & $29.9 \%$ & $29.9 \%$ \\
\hline
\end{tabular}

Tabel 4. Mean Different Denyut Nadi Skala Kecil

\begin{tabular}{ccccc}
\hline & Mean & $\mathrm{N}$ & $\begin{array}{c}\text { Std. } \\
\text { Deviation }\end{array}$ & $\begin{array}{c}\text { Std. Error } \\
\text { Mean }\end{array}$ \\
\hline NadiPre & 90 & 3 & 6.0 & 3.4 \\
NadiPost & 124 & 3 & 3.4 & 2.0 \\
\hline
\end{tabular}

Rata-rata denyut nadi sebelum melakukan latihan adalah 90x per menit dan setelah melakukan latihan meningkat rata-rata $120 \mathrm{x}$ per menit. Dengan selisih kenaikan 30x per menit. Untuk lebih jelas dapat dilihat pada Gambar 1.

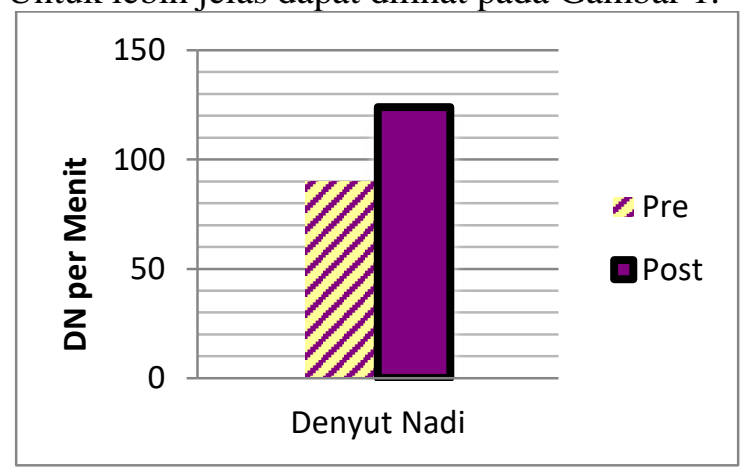

Gambar 1. Peningkatan Denyut Nadi Skala Kecil

Penilaian pre dan posttest berikutnya adalah dengan mengukur penurunan persentase lemak. Dari hasil uji coba skala kecil di peroleh perbedaan penurunan persentase lemak yang tidak terlalu besar antara sebelum latihan dan sesudah latihan seperti dipaparkan dalam Tabel 5 . 
Tabel 5. Mean Different Denyut Nadi Penurunan Persentase Lemak Skala Kecil

\begin{tabular}{ccccc}
\hline & Mean & $\mathrm{N}$ & $\begin{array}{c}\text { Std. } \\
\text { Deviation }\end{array}$ & $\begin{array}{c}\text { Std. Error } \\
\text { Mean }\end{array}$ \\
\hline LemakPre & 30.5 & 3 & 0.60 & 0.34 \\
LemakPost & 30.1 & 3 & 1.04 & 0.60 \\
\hline
\end{tabular}

Secara keseluruhan terdapat penurunan rata-rata persentase lemak sebelum dan sesudah latihan, meskipun sangat kecil dengan selisih $0,4 \%$. Untuk lebih jelas melihat perbandingan penurunan persentase lemak sebelum dan sesudah latihan, dipaparkan pada Gambar 2.

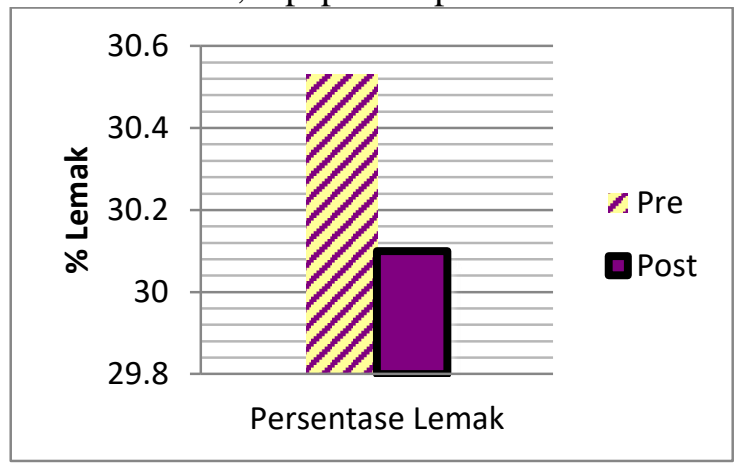

Gambar 2. Penurunan Persentase Lemak Skala Kecil

Dari paparan Gambar 2, terjadi selisih penurunan persentase lemak rata-rata $0,4 \%$. Dengan persentase lemak rata-rata sebelum melakukan latihan adalah $30.5 \%$ dan sesudah melakukan latihan $30.1 \%$.

\section{Analisis Data Hasil Uji Coba Skala Besar}

Uji Pelaksanaan Produk

Setelah melalui tahap uji coba skala kecil selanjutnya produk siap untuk diuji coba skala besar. Uji coba skala besar dilakukan di kolam renang FIK UNY dengan jumlah 6 sampel yang keseluruhannya adalah wanita yang mengalami masalah kenaikan berat badan (overweight). Tujuan dari skala besar ini untuk mengumpulkan data yang lebih akurat terhadap penerimaan produk, kualitas dan kelayakan produk dalam membakar lemak untuk program penurunan berat badan pada overweight. Uji pelaksanaan dinilai oleh sampel yang menjadi sebagai tester pada produk ini dengan mengisi penilaian pada kuesiner. Dari kuesioner yang diberikan pada sampel maka di peroleh penilaian pada Tabel 6 .

Dari data Tabel 6 dijelaskan untuk nilai lebih dari 4.21 dengan kategori "Sangat Baik" mendapatkan frekuensi 3, untuk nilai 3,41-4,21 dengan kategori "Baik" mendapat frekuensi 3. Untuk rentang nilai dari 2.61 sampai 3.40 dengan kategori "Cukup" tidak ada, untuk nilai dari 1.80 - 2.60 dengan kategori "Kurang" tidak ada dan untuk nilai di bawah 1.76 dengan kategori "Sangat Kurang" tidak ada.

Tabel 6. Penilaian Uji Pelaksanaan Skala Kecil

\begin{tabular}{|c|c|c|c|c|}
\hline No. & Interval & Kategori & f & $\%$ \\
\hline 1 & $>4.21$ & Sangat Baik & 3 & 50 \\
\hline 2 & $3.41-4.21$ & Baik & 3 & 50 \\
\hline 3 & $2.61-3.40$ & Cukup & - & - \\
\hline 4 & $1.80-2.60$ & Kurang & - & - \\
\hline 5 & $<1.79$ & Sangat Kurang & - & - \\
\hline \multicolumn{3}{|c|}{ Total } & & 100 \\
\hline
\end{tabular}

\section{Uji Kelayakan Penilaian Ahli}

Berdasarkan hasil penilaian para ahli dapat disimpulkan rata rata berdasarkan Tabel 7.

Tabel 7. Rata-rata Penilaian Ahli Skala Besar

\begin{tabular}{clcc}
\hline No. & Validator & Skor & Kategori \\
\hline 1 & Ahli Kebugaran Jasmani & 4 & Baik \\
2 & Ahli fisiologi & 3.8 & Baik \\
3 & Ahli Renang & 3.7 & Baik \\
Jumlah & 11.5 & BAIK \\
Rata-rata skor & 3.8 & \\
\hline
\end{tabular}

Ahli kebugaran jasmani memberikan nilai rata-rata 4 dengan kategori "Baik". Untuk ahli fisiologi memberikan nilai rata-rata 3.8 "Baik" dan ahli renang memberikan nilai 3.7 dengan kategori "Baik"

\section{Data Pre dan Posttest Skala Besar}

Untuk aspek yang diukur tidak jauh berbeda dengan uji coba skala kecil yaitu mengukur peningkatan denyut nadi per menit dan penurunan persentase lemak sebelum dan sesudah latihan. Teknik analisis data uji coba skala besar adalah analisis deskriptif yang menggambarkan rata-rata peningkatan pre dan post peningkatan denyut nadi dan memperkirakan penurunan persentase lemak. Tabel 8 merupakan ringkasan perolehan data dari hasil uji coba skala besar.

Tabel 8. Data Pre dan Posttest Skala Besar

\begin{tabular}{cccccc}
\hline \multirow{2}{*}{ No. } & \multirow{2}{*}{ Sampel } & \multicolumn{2}{c}{ Denyut/ menit } & \multicolumn{2}{c}{ \% Lemak } \\
\cline { 3 - 6 } & & Pre & Post & Pre & Post \\
\hline 1 & A & 84 & 132 & 30.7 & 30.5 \\
2 & B & 90 & 126 & 29.6 & 29.6 \\
3 & C & 108 & 138 & 29.3 & 29.1 \\
4 & D & 102 & 132 & 38.8 & 38.7 \\
5 & E & 90 & 120 & 32.4 & 32.4 \\
6 & F & 108 & 144 & 41.3 & 41.2 \\
\hline
\end{tabular}


Jurnal Keolahragaan 6 (2), 2018 - 147

Rahmat Sanusi, W. Widiyanto

Tabel 9. Mean Different Denyut Nadi Skala Besar

\begin{tabular}{lcccc}
\hline & Mean & $\mathrm{N}$ & $\begin{array}{c}\text { Std. } \\
\text { Deviation }\end{array}$ & $\begin{array}{c}\text { Std. Error } \\
\text { Mean }\end{array}$ \\
\hline NadiPre & 97 & 6 & 10.33 & 4.21 \\
NadiPost & 132 & 6 & 8.48 & 3.46 \\
\hline
\end{tabular}

Dari data Tabel 9 dikemukan bahwa ratarata denyut nadi sebelum melakukan latihan aquarobic exercise adalah $97 x$ per menit dan setelah melakukan latihan meningkat menjadi 132 per menit. Peningkatan rata-rata denyut nadi ini sejalan dengan target latihan yang berpatokan pada intensitas latihan 60-70\% dari denyut nadi maksimal yang berada di kisaran 117x hingga $137 x$ per menit. Untuk lebih jelas melihat peningkatan denyut nadi sebelum dan sesudah latihan dapat dilihat pada Gambar 3.

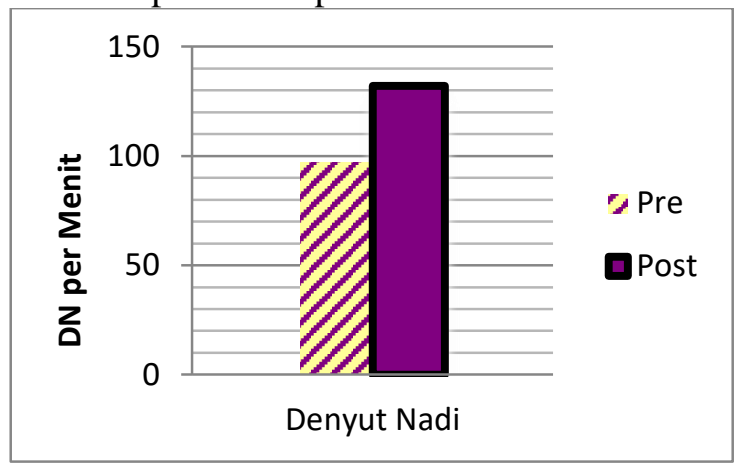

Gambar 3. Peningkatan Denyut Nadi Skala Besar

Pengukuran selanjutnya adalah mengukur pengurangan persentase lemak sebelum dan sesudah melakukan latihan. Berikut analisis ratarata penurunan persentase lemak setelah melakukan latihan aquarobic exercise:

Tabel 10. Mean Different Penurunan Persentae Lemak Skala Besar

\begin{tabular}{lcccc}
\hline & Mean & $\mathrm{N}$ & $\begin{array}{c}\text { Std. } \\
\text { Deviation }\end{array}$ & $\begin{array}{c}\text { Std. Error } \\
\text { Mean }\end{array}$ \\
\hline LemakPre & 33.6 & 6 & 5.11 & 2.08 \\
LemakPost & 33.5 & 6 & 5.11 & 2.09 \\
\hline
\end{tabular}

Dari paparan data Tabel 10 dapat dilihat bahwa rata-rata persentase lemak sebelum melakukan latihan adalah $33.68 \%$ dan setelah melakukan latihan menjadi $33.58 \%$. Persentase penurunan lemak sangat sedikit dengan asumsi peneliti penurunan persentase lemak tidak terlalu signifikan. Untuk lebih jelas melihat perkiraan penurunan persentase lemak dapat dilihat pada Gambar 4.

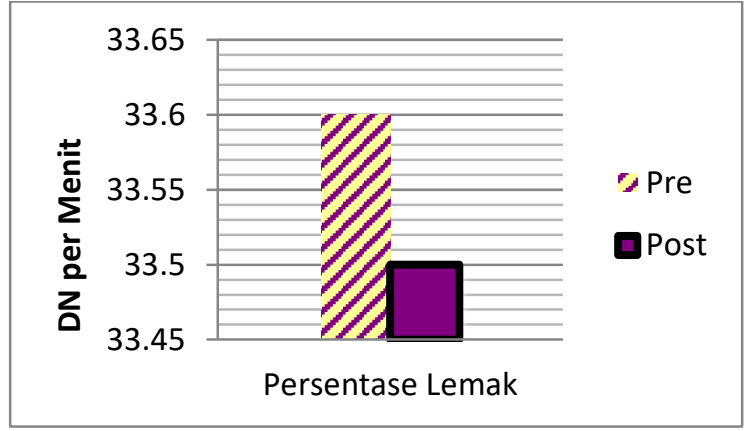

Gambar 4. Penurunan persentase Lemak Skala Besar

Gambar 4 menunjukkan adanya peningkatan rata-rata denyut nadi per menit dan perkiraan penurunan persentase lemak. Untuk skala kecil diperoleh nilai rata-rata denyut nadi dari pre test sebesar 90x per menit dan pada post test nilai rata-rata peningkatan denyut nadi sebesar $124 \mathrm{x}$ per menit dengan selisih rata-rata peningkatan sebesar $34 \mathrm{x}$ per menit. Untuk skala besar, perolehan rata-rata denyut nadi pre test sebesar 97x per menit dan untuk pada post test sebesar $132 \mathrm{x}$ per menit yang berarti terdapat selisih peningkatan denyut nadi per menit sebesar $57 \mathrm{x}$ per menit. Untuk perkiraan persentase lemak, pada uji coba skala kecil, rata-rata persentase lemak pretest sebesar 30,5\% dan untuk persentase lemak post test sebesar 30,1\% dengan selisih rata-rata penurunan persenatse lemak sebesar $0,4 \%$. Untuk skala besar, persentase lemak pre test diperoleh sebesar $33,6 \%$ dan persentase lemak setelah posttest sebesar $33,5 \%$ dengan selisih rata-rata penurunan sebesar $0.1 \%$.

Dari hasil data yang diperoleh melaui pre dan posttest dapat diketahui bahwa terjadi peningkatan peningkatan denyut nadi selama latihan dan perkiraan penurunan persentase lemak setelah melakukan latihan. Dengan demikian dapat disimpulkan bahwa model aquarobic exercise yang dikembangkan efektif, layak dan dapat digunakan dalam membakar lemak pada overweight.

\section{SIMPULAN}

Berdasarkan hasil penelitian yang telah dijelaskan pada bagian pembahasan, secara garis besar dapat di simpulkan bahwa model latihan yang dikembangkan bertujuan menciptkan latihan alternatif untuk proses pembakaran lemak bagi orang dengan masalah berat badan. Berikut ini adalah kesimpulan dari produk yang dikembangkan oleh peneliti. Pertama, Bentuk aquarobic exercise untuk pembakaran lemak pada overweight ini terdiri dari 16 gerakan yang 
tersusun dari 5 gerakan pemanasan, 6 gerakan inti dan 5 gerakan pendinginan. Latihan dilakukan di air ketinggian 90-100 cm dengan intensitas latihan $60-70 \%$ dari denyut nadi maksimal dan durasi latihan maximal 35 menit. Model aquarobic exercise ini dapat digunakan membakar lemak pada overweight untuk program penurunan berat badan dengan asumi, latihan ini dilakukan secara teratur dan terprogram disertai dengan program pengaturan nutrisi. Dari segi intensitas latihan, bentuk gerakan, irama gerakan, volume latihan dari model ini tidak jauh berbeda dengan latihan senam aerobik pada umumnya sehingga mudah untuk dilakukan. Model aquarobic exercise ini merupakan model latihan alternatif dalam membakar lemak pada overweight. Kedua, Kelayakan model aquarobic exercise. Dari hasil penilaian para ahli, yaitu ahli kebugaran jasmani, ahli fisilogi, dan ahli renang produk ini mendapatkan penilaian dengan kategori "Baik". Dapat disimpulkan bahwa produk ini layak digunakan sebagai latihan untuk membakar lemak pada overweight. Ketiga, Efektivitas model aquarobic exercise. Pertama, produk ini merupakan latihan non-traumatic yang efektif dalam mengatasi masalah osteoathritis pada overweight dan membantu orang dengan overweight untuk lebih aktif bergerak ketika melakukan latihan ini. Keempat, keterbatasan peneliti tentang jumlah sampel disebabkan kurang tertariknya orang dengan overweight/ obesitas untuk megikuti program latihan aquarobic exercise dan kemampuan untuk mengontrol sampel agar konsisten dalam mengikuti latihan hingga selesainya program latihan. Semakin banyak sampel akan memberikan keakuratan nilai keberhasilan yang lebih tinggi.

\section{DAFTAR PUSTAKA}

Akoso, B. T. (2012). Budi daya sapi perah jilid 1. Airlangga University Press.

Bocalini, D. S., Serra, A. J., Murad, N., \& Levy, R. F. (2008). Water-versus land-based exercise effects on physical fitness in older women. Geriatrics \& Gerontology International, 8(4), 265-271.

Chan, F. (2012). Strength training (Latihan kekuatan). Cerdas Sifa Pendidikan, 1(1).

Fanny, A., \& Suardiman, S. (2013). Pengembangan multimedia interaktif untuk mata pelajaran ilmu pengetahuan sosial (IPS) sekolah dasar kelas V. Jurnal Prima Edukasia, 1(1), 1-9. doi:https://doi.org/10.21831/jpe.v1i1.2311
Gappmaier, E., Lake, W., Nelson, A. G., \& Fisher, A. G. (2006). Aerobic exercise in water versus walking on land: Effects on indices of fat reduction and weight loss of obese women. Journal of Sports Medicine and Physical Fitness, 46(4), 564.

Hagag, A. A. (2013). Effect of aerobic exercises on plasma lipid profile and cardiorespiratory fitness in obese women. Indian Journal of Physiotherapy and Occupational Therapy, 7(3), 104-108.

Hutabarat, J. C. J. (2016). Perancangan aplikasi menentukan berat badan ideal dengan menggunakan algoritma K-Means clustering. JURIKOM (Jurnal Riset Komputer), 3(5).

Kang, J. (2018). Nutrition and metabolism in sports, exercise and health. Routledge.

Kementerian Kesehatan Republik Indonesia. (2013). Riset kesehatan dasar nasional (Riskesdas) 2013. Jakarta: Badan Penelitian dan Pengembangan Kesehatan Departemen Kesehatan, Republik Indonesia Desember.

Mahato, R. I. (2005). Water insoluble and soluble lipids for gene delivery. Advanced drug delivery reviews, 57(5), 699-712.

McArdle, W.D., Frank, F.I., \& Katch, V.L. (2010). Exercise physiology nutrition, energy, and human performance. Philadelphia: Lippincott Williams \& Wilkins.

Penggalih, M., Hardiyanti, M., \& Sani, F. (2015). Perbedaan perubahan tekanan darah dan denyut jantung pada berbagai intensitas latihan atlet balap sepeda. Jurnal Keolahragaan, 3(2), 218-227. doi:https://doi.org/10.21831/jk.v3i2.4949

Plowman, S. A., \& Smith, D. L. (2014). Exercise physiology. Philadelphia: Lippincott Williams \& Wilkins.

Qodriyah, S., \& Wangid, M. (2015). Pengembangan SSP tematik integratif untuk membangun karakter kejujuran dan kepedulian siswa SD kelas II. Jurnal Prima Edukasia, 3(2), 177-189. doi:https://doi.org/10.21831/jpe.v3i2.7222

Sukadiyanto, S. (2011). Pengantar teori dan metodologi melatih fisik. Bandung: Lubuk Agung. 


\section{Jurnal Keolahragaan 6 (2), 2018 - 149}

Rahmat Sanusi, W. Widiyanto

Sugiyono, S. (2012). Metode penelitian kuantitatif, kualitatif dan $R \& D$. Bandung: Alfabeta.

Suharjana, S. (2013). Kebugaran jasmani. Yogyakarta: Jogja Global Media.

Sharkey, B. J. (1990). Physiology of fitness. Human Kinetics

Sukardjo, S. (2005). Evaluasi pembelajaran . Diktat mata kuliah evaluasi pembelajaran.Prodi TP PPs UNY
Tomihiro, S., \& Noriko, T,. (2004). Water exercises: Workouts with the aqua noodle. UK : Meyer \& Meyer Sport.

Verhargen, A.P., Cardoso, J.R., \& BiermaZeinstra, S.M.A. (2012). Aquatic exercise \& balneotherapy in musculoskeletal Conditions. Journal of Best Practice \& Research Clinical Rheumatology, 26, 335$343 .$. 